\title{
INSTITUTIONAL TRUST IN THE CASE OF CROATIAN REGIONS
}

Summary: Institutions and institutional trust can be marked as important determinants of (regional) growth and development in contemporary literature. Aim of this paper is to analyse institutional trust in two Croatian counties and to compare those results with earlier theoretical findings. The methodology consists of in-depth interviews made by survey of counsellors or some of leading functions in two Croatian counties.

The results are mostly in accordance with earlier theory findings of institutional trust for Croatian level, i.e. the highest level of institutional trust was related with traditional values, for instance in family, while in some institutions trust varied and had a gap in level of respondents trust, depending of their own experience, for instance in self-government and educational system. At very low level of institutional trust were for instance, political parties and Government. As singled out, some of the main obstacles in achieving high levels of institutional trust were corruption, inconsistency in decision-making and enforcement, noncompliance, slow and complicated procedures, non-transparency, politization. Trust in institutions according to the results, impacts reduction and regulation of uncertainty in the economy. These results could be very worth and a certain guide for policy makers and their future decision-making.

Keywords: $\quad$ institutions; regional development; Republic of Croatia

\footnotetext{
Dubravka Jurlina Alibegović, PhD, Senior Research Fellow, The institute of economics Zagreb, Trg J. F. Kennedyja 710000 Zagreb. E-mail address: djurlina@eizg.hr. ORCID: https://orcid.org/0000-0002-0424-7583.

** Katarina Marošević, PhD, Assistant Professor, Faculty of Law, Josip Juraj Strossmayer University of Osijek, S. Radića 13, 31000 Osijek. E-mail address: katarina.marosevic@pravos.hr. ORCID: https://orcid.org/0000-0002-8727-130X.
} 


\section{INTRODUCTION}

Trust is an important precondition for growth, social well-being and governance. ${ }^{1}$ Research on this topic has intensified in recent decades, in various sciences and fields (Welter and Smallbone 2006; Nooteboom 2007) but is still under-explored. ${ }^{2}$ There are many different definitions of trust, and the ambiguity is best illustrated by the following: "There is no single comprehensive definition of trust, and even within disciplines several definitions often exist."

Usually, the basic distinction is made between interpersonal trust, meaning trust in other people, and trust in institutions or institutional trust. Habibov points out that "individuals with higher levels of trust were more likely to support social welfare as a priority for government spending. Therefore, the lack of institutional trust at the individual level has translated into strong anti-welfare sentiment." ${ }^{4}$ OECD defines institutional trust as following: "Institutional trust refers to trust in all types of institutions, with trust in political, law, and non-governmental institutions used to refer to a narrower concept." Mrakovčić and Vuković emphasize the endogeneity of trust in institutions, aimed at the rational attitude of citizens who evaluate the work of institutions. ${ }^{6}$ The rule is that institutions that perform well create greater confidence, while the negatively assessed performance of institutions causes distrust and skepticism. Improving trust in public institutions, as highlighted by Cole and Cohn, is ensured by information and engaging citizens in decision making. ${ }^{7}$ Trust also differs in terms of certain characteristics, such as education and household income and age, so, for example, Hudson states that unemployed persons tend to have a lower level of trust not only in basic economic institutions-government and the Central Bank, but also in other state institutions such as the law enforcement and legal institutions. ${ }^{8}$ Furthermore, Hakhverdian and Mayne claim that the impact of education is evident as a conditional and conditioning effect on institutional trust. As the same authors state, education is negatively related to institutional

1 OECD, OECD Guidelines on Measuring Trust, OECD Publishing, Paris, 2017. http://dx.doi.org/10.1787/9789264278219-en. Accessed December 52020.

2 See more: Welter, F.; Smallbone, D., Exploring the Role of Trust in Entrepreneurial Activity, Entrepreneurship, Theory \& Practice, Vol. 30, Issue 4, 2006, p. 465-475. DOI: 10.1111/j.1540-6520.2006.00130.x. and in: Nooteboom, B., Social Capital, Institutions and Trust, Review of Social Economy, Vol. 65, Issue 1, Beyond Social Capital, 2007, p. 29-53. DOI: 10.1080/00346760601132154. Accessed May 222020.

3 Welter, F.; Smallbone, D., Exploring the Role of Trust in Entrepreneurial Activity, Entrepreneurship, Theory \& Practice, Vol. 30, Issue 4, 2006, p. 465-475.; (p. 465)., DOI: 10.1111/j.1540-6520.2006.00130.x. Accessed March 222020.

4 Habibov, N., Individual and Country-level Institutional Trust and Public Attitude to Welfare Expenditures in 24 Transitional Countries, The Journal of Sociology \& Social Welfare, Vol. 41, Issue 4, 2014, p. 23-48, (p. 41). https://scholarworks.wmich.edu/ jssw/vol41/iss4/3. Accessed March 222020.

5 OECD, op. cit. note 1, p. 11.

6 Mrakovčić, M.; Vuković, D., 'Unutarnja' kriza pravosuđa? Stavovi pripadnika pravničkih profesija o pravosuđu u Hrvatskoj i Srbiji, The "Internal" Crisis of the Judiciary? Attitudes of Legal Profession Members on the Judiciary in Croatia and Serbia]. Politička misao, Vol. 56, Issue 1, 2019, p. 75-105, (p. 77). DOI: 10.20901/pm.56.1.03.; according to Mishler and Rose 2005:1054. Accessed March 222020.

7 Cole, L.; Cohn, E., Institutional Trust Across Cultures: Its Definitions, Conceptualizations, and Antecedents Across Eastern and Western Euroean Nations, u: Interdisciplinary Perspectives on Trust: Towards Theoretical and Methodological Integration, Springer, Cham-Heidelberg-New York-Dordrecht-London, 2016, p. 157-176. DOI: 10.1007/978-3-319-22261-5. Accessed April 32020 .

8 Hudson, J., Institutional Trust and Subjective Well-Being accroaa the EU, Kyklos, International Review for Social Sciences, Vol. 59, Issue 1, 2006, p. 43-62. DOI: 10.1111/j.1467-6435.2006.00319.x. Accessed March 222020. 
trust in corrupt societies, and positively related to institutional trust in non-corrupt societies. Furthermore, the corrosive effect of corruption on institutional trust worsens as education improves. ${ }^{9}$ Sekulić and Šporer state that trust in institutions is important as it determines the way society functions, but also gives warning about the satisfaction of individuals. Furthermore, it is clear that individuals satisfy their needs and regular activity through institutional form if possible, and due to low confiedence they bypass such institutions and resort to other forms of interaction. ${ }^{10}$

Building and maintaining institutional trust is central to the creation of democratic societies, since negative experiences with government or other institutions can have extremely profound negative effects, even greater than the effect of positive experiences. ${ }^{11}$ Cole and Cohn state that good governance generates trust and corruption constitutes a fundamental barrier to trust in institutions and thus threatens the relationship between government and its citizens. ${ }^{12}$ In lieu with aforementioned and the obvious importance of the subject of trust in institutions, the aim of this paper is to analyse institutional trust in two Croatian counties, Osijek-Baranya County and City of Zagreb, since trust in institution is/can be one of outstanding obstacles in achieving growth and development.

The first part of the paper focuses on reviewing the literature on the issue of trust in institutions. Then attention is drawn to reflections on trust in institutions in the Republic of Croatia. After that, results of a survey/in-depth interview obtained by feedback at the county level of the Republic of Croatia as the central topic of this work. Finally, the conclusions are drawn with reference to the current state of affairs in the Republic of Croatia, taking into consideration the theoretical and analytical part of the paper.

\section{LITERATURE REVIEW}

Talking about trust in institutions, Mrakovčić and Vuković singled out two schools of thought: the cultural and the institutional. According to the same authors, the culturalist tradition cites three main arguments about trust as a prerequisite for functional democracy: trust increases support for a democratic regime, enables the public to accept democratic values and ideals and reject undemocratic alternatives, and increases the quantity and quality of political participation. The above refers to trust in institutions as exogenous, and one that comes from outside the political sphere and arises from attitudes about people who are deeply embedded in cultural norms and beliefs inherited in the early stages of socialization, and interpersonal trust from childhood turns into trust in institutions. The institutional perspective sees trust

9 Hakhverdian, A.; Mayne, Q., Institutional Trust, Education, and Corruption: A Micro-Macro Interactive Approach, The Journal of Politics, Vol. 74, Issue 3, 2012, p. 739-750. DOI: abs/10.1017/S0022381612000412. Accessed March 222020.

Sekulić, D.; Šporer, Ž., Gubimo li povjerenje u institucije?, [Do We Lose Confidence in Institutions], u: Korupcija i povjerenje. [Corruption and Trust], Centar za demokaciju i pravo, Zagreb, 2010, p. 71-117. https://tripalo.hr/knjige/KorIPovj/sekulicSporer. pdf. Accessed March 222020.

11 Ward, P. R;, Miller, E.; Pearce, A. R.; Meyer, S. B., Predictors and Extent of Institutional Trust in Government, Banks, the Media and Religous Organisations: Evidence from Cross-Sectional Surveys in Six Asia-Pacific Countries, PLoS One, Vol. 11, Issue 10, 2016. DOI: 10.1371/journal.pone.0164096. Accessed March 222020. 
in institutions as endogenous and related to the work of institutions, and it includes the rational attitude of citizens which evaluates the work of institutions in such a way that those institutions that work well create greater confidence, and those that do not work well create cause distrust and skepticism. ${ }^{13}$

Research into institutional trust is insufficient, and as stated in one of the OECD documents "[...] Trust in other people and trust in institutions are essential ingredients for social and economic progress [...]." ${ }^{14}$ Hwang cites an increasing number of studies on the importance of trust and economic growth, but they mainly refer to interpersonal trust. Hwang, on the other hand, confirms that institutional trust is most robustly linked to economic growth, citing results of conducted research in 46 countries as an example. ${ }^{15}$ An interesting stance is taken by Moreno et al.: "Trust between citizens and institutions of memory nowadays are twofold. Citizens must trust institutions, but also institutions must trust citizens in order to make them participants." ${ }^{16}$ Trust in institutions, as it emphasises Habibov, played an exceptional role in establishing a welfare state in, for example, Germany and Sweden. ${ }^{17}$

Sources of institutional trust are discussed by Campbell, stating that cultural explanations that focus on civic engagement compete with rationalist theories that link institutional trust and perceived economic performance. ${ }^{18}$ Other aspects, for instance, relations and building of institutional trust through e-government as trustworthy signals are discussed by Smith. ${ }^{19}$

Cole and Cohn in their research question the philosophical issues surrounding cross-cultural conceptualizations of institutional trust. They point out that they compare predictors of diffuse support for the highest national court in the country as a measure of institutional trust between Western European and Eastern European countries. ${ }^{20}$ Zsolt and Gergõ, while comparing the situation of the countries of Western Europe and the new democracies of East Central Europe at the same time indicate a much lower degree of institutional trust in Eastern Europe. Similar to Western Europe, institutional confidence in the countries of East Central Europe is positively associated with success in social and economic life. The authors emphasize the need to be concerned about low confidence rates and therefore Zsolt and Gergõ state that trust in state institutions is an indicator of the public approval and legitimacy of a political

13 Mrakovčić, M.; Vuković, D., op. cit., note 6, p. 75-105.

14 OECD, op. cit., note 1, p. 3.

15 Hwang, I. D., Which Type of Trust Matters?: Interpersonal vs. Institutional vs. Political Trust, Seoul: Bank of Korea WP 2017-15, 2017, http://dx.doi.org/10.2139/ssrn.2967051. Accessed January 112020.

16 Moreno, E. A.; Ghezzi, A.; Gemo, M.; Tallacchini, M.; Pereira, A. G., Institutional Trust: Beyond Transparency, Luxembourg: Euopean Commission, JRC Science and Policy Reports, 2014, p. 34, https://publications.jrc.ec.europa.eu/repository/bitstream/ JRC93048/lbna27286enn.pdf. Accessed April 22020.

17 Habibov, N.; Cheung, A.; Auchynnikava, A., Does Institutional Trust Increase Willingness to Pay More Taxes to Support the Welfare State?, Sociological Spectrum, Vol. 38, Issue 1, 2018, p. 51-68. DOI: 10.1080/02732173.2017.1409146. Accessed March 22 2020.

18 Campbell, W. R., The Sources of Institutional Trust in East and West Germany: Civic Culture or Economic Performance?, German politics, Vol. 13, Issue 3, 2007, p. 401-418, DOI: 10.1080/0964400042000287437. Accessed March 222020.

19 Smith, M., Building institutional trust through e-government trustworthiness cues, Information Technology \& People, Vol. 23, Issue 3, 2010, p. 222-246. DOI: 10.1108/09593841011069149. Accessed March 222020. 
system, and therefore low trust levels should be a cause for concern. ${ }^{21}$ Sekulić and Šporer state that the level of trust in domestic institutions serves as a good indicator of consensus and satisfaction with the current regime, but may also be the reason for the current situation. ${ }^{22}$

Interesting results on the effects of institutional confidence in the willingness to pay higher taxes to support the welfare state, are pointed out by Habibov, Cheung, and Auchynnikava, with the results suggesting that there is a positive effect of institutional confidence in the willingness to pay higher taxes to support the welfare of the state and that institutional trust should be seen as an extremely important mechanism for protecting the welfare state. ${ }^{23}$

In following chapter more attention is paid to research on trust in institutions in the Republic of Croatia. There are some theoretical findings presented with emphasize of the research that Eastern European countries have lower levels of trust in institutions than those in Western Europe.

\subsection{INSTITUTIONAL TRUST IN REPUBLIC OF CROATIA: REVIEW OF SELECTED RESEARCH}

The degree of trust is an indicator of institutional development, and besides, it emphasizes that Croatia has an extremely low level of mutual trust among its inhabitants. ${ }^{24}$ Institutional environment importance is emphasized by Aralica and Budak; testing the assumption that good governance is connected to economic and social development in order to confirm that the quality of governance should be evaluated by considering the country's specific institutional environment. ${ }^{25}$ Matić points out that democracy can be developed in a society in which there is a high degree of trust and in which citizens will be prepared to act for the common good and that in modern societies trust is not automatically a product of culture, but an active political achievement, a phenomenon that rests on the continuity of certain fundamental institutional characteristics of society. The creation, trust and stability of a democratic order is aided by a just and responsible government as well as institutions that are guided by the norms of telling the truth, fulfilling promises, honoring treaties, fairness and solidarity. ${ }^{26}$

The achieved results of trust in certain institutions of the Republic of Croatia are presented with some of following researches, for instance, Baloban and Rimac investigated trust in some institutions in Croatia in the general population, with the highest confidence in the Church,

21 Zsolt, B.; Gergo, M.-B., Does Institutional Trust in East Central Europe Differ from Western Europe?, European Quarterly of Political Attitudes and Mentalities, Vol. 3, Issue 2, 2014, p. 1-17, https://search.proquest.com/openview/ da2c02703e0fcb22da31383885a32b08/1?cbl=203088. Accessed March 222020.

22 Sekulić, D.; Šporer, Ž., op. cit., note 10.

23 Habibov, N., Cheung, A., Auchynnikava, A., op. cit., bilj. 17.

24 Bejaković, P., Labor Force Competitiveness in Croatia: Status and Problems, u: Konkurentnost hrvatske radne snage [Competitiveness of the Croatian Labor Force], Institut za javne financije, Zagreb, 2004, p. 1-13.

25 Aralica, Z.; Budak, J., Institutional Development and Good Governance Assessments in Croatia: An Extended Focus on Corruption, Zagreb International Review of Economics \& Business Conference Issue, SCI (1), 2004, p. 17-34. https://hrcak.srce.hr/101270. Accessed March 222020.

26 Matić, D., Demokracija, povjerenje i socijalna pravda [Democracy, Trust and Social Justice]. Revija za sociologiju Vol. 31, Issue 3-4, 2000, p. 183-195. https://hrcak.srce.hr/154303. Accessed March 222020. 
the military, the school, and the police as institutions concerned with the physical and psychological stability of a war-affected society, while they have the least confidence in the media and new private companies. ${ }^{27}$ The coupling of the Church together with the state institutions indicates that the traditional value pattern was largely present in Croatia in the time of survey conduction.

On the other hand, the institutions belonging to the group of those in whom the respondents trust are the human rights movement, the environmental movement, the institutions of the legal system, the Croatian Catholic Radio and the women's movement, which suggests that the relatively prominent confidence was noted in the new movements that were pointing to elements of post-materialist values. ${ }^{28}$ In line with the above results, although more recent, Trzun states that in several examinations of the degree of trust in state institutions with a particular focus on the Croatian armed forces, it is precisely the military that is at the top of institutions that the local public trusts and maintains a high level of trust for years which is especially important in the face of a great decline in confidence in the institutions of the state. As Trzun points out, due to the rapid decline in trust in the institutions of the state, the process of democratization and exit from a patriarchal society characterized by skepticism and low level of interpersonal trust is difficult, and for this reason rare institutions that are trusted can serve as the basis on which to gradually direct awareness towards new values. The same author emphasizes the need for better communication with the public, especially with younger generations, who are less impressed with traditional values and old successes. ${ }^{29}$ Franc and Međugorac also point out that only a few studies address trust in institutions among young people (e.g. as quoted in Ilišin 2005; Ilišin et al. 2013; Gvozdanović 2014) ${ }^{30}$ It can be confirmed that certain attitudes regarding institutional trust has been changed through time of 90's to and contemporary ones.

Research by Sekulić and Šporer is also in line with the reported trends of trust in institutions. It compares the percentage of respondents in 2004 and 2010 and shows that for these two periods, institutions in which citizens show less confidence are measured by the relative magnitude of the decline in confidence in it: the Church $(-14.4 \%)$, Parliament $(-4.3 \%)$, the Government $(-3.3 \%)$ and the military $(-3.1 \%)$. It is important to emphasize that the percentage of confidence expressed by citizens in 2010, regardless of the decline, is at different levels for the four institutions. In this ranking, the highest percentage of citizens' trust was recorded as trust in the military $(65.6 \%)$ and more than half of the citizens expressed trust in the Church (53.1\%), while just over a quarter of respondents (25.4\%) trusted parliament and slightly more trusting the government (28.6\%). ${ }^{31}$ Franc and Međugorac emphasize the

27 Baloban, S., Rimac, I., Povjerenje u institucije [Trust in Institutions]. Bogoslovska smotra, Vol. 68, Issue 4, 1998 , p. 663-672. https://hrcak.srce.hr/31611. Accessed March 222020.

28 Ibidem.

29 Trzun, Z., Kriza povjerenja u institucije: Istraživanje povjerenja u vojsku [Institutional Confidence Crisis: Exploring the Trust in the Army]. Polemos: časopis za interdisciplinarna istraživanja rata i mira, Vol. 15, Issue 29, 2012, p. 33-54. https://hrcak.srce. hr/92832. Accessed March 222020

30 Franc, R.; Međugorac, V., Mladi i (ne)povjerenje u institucije: moguće odrednice i posljedice, [Youth and (Un)Trust in institutions: Possible Determinants and Consequences], in: Demokratski potencijali mladih u Hrvatskoj [Youth Democratic Potential in Croatia], Institut za društvena istraživanja u Zagrebu Centar za demokraciju i pravo Miko Tripalo Zagreb, Zagreb, 2015, p. 47-65. 
trust of Croatian citizens, who trust to the military, police and the Church the most, and to political parties the least (e.g. as quoted in Baloban and Rimac 1998; Sekulić and Šporer 2010; Pilar's Barometer of Croatian Society 2014). ${ }^{32}$ Mrakovčić states that respondents from the conflict areas show a greater degree of trust in social institutions then the respondents from the peaceful areas. Furthermore, reasons for these differences in trust in institutions also differ, with foundational values of Europeanism, rejection of social pesimism and the level of education of the respondents being key in the peaceful areas. Meanwhile, in conflict areas, in addition to the aforementioned factors, the nationalistic value system rooted in the acceptance of ethnocentrism and the right-wing political orientation also plays a vital role. ${ }^{33}$

A survey of the Standard Eurobarometer 90 implies that Croats trust radio and television the most, but although EU confidence in media has stagnated over the past year, it has declined in Croatia, except for television that has grown slightly. Although Croats trust in online news more than the average European, especially in news from online social networks, this rate is dropping among Croats as well as at EU28 ${ }^{34}$ level. In terms of trust in the judiciary system, more than of half of Europeans trust in their judiciary system, but not even a quarter of Croats. The military enjoys a great deal of trust from both Croats and Europeans, while trust in the police is noticeably higher at EU28 level than in Croatia. Confidence in public administration at EU28 level is growing and half of Europeans now trust it, while it is still in decline in Croatia. The average European citizen trusts the county and local authorities more and more, while the Croats overwhelmingly do not trust them. Distrust in national parliaments is dominant both at EU28 level and in Croatia, but at different levels; while at EU level confidence is stagnant at just over a third, in Croatia parliament is trusted by less than a fifth of respondents, which is about the same trust rate as the government. Distrust in political parties is enormous on both sides. At EU28 level, confidence in the European Union is growing slightly, most are distrustful of it, while trust in the EU in Croatia has increased significantly. Confidence in the European Commission is also growing at EU28 level and in Croatia. Most Europeans, and even Croats, do not trust the European Central Bank, although confidence is in the process of growing and distrust is waning. In Croatia, this distrust is at half-level. As for the European institutions, both at EU28 and in Croatia, the European Parliament enjoys the confidence of $48 \%$ of average Europeans and $50 \%$ of Croatian respondents. ${ }^{35}$ Kaliterna-Lipovčan and Brajša-Žganec state that Croatian citizens have lower confidence in government institutions (government, parliament, judiciary, regional/local authorities). Confidence in regional and/or local authorities is extremely low, with Croatia in last place within EU28. Residents of northwestern Croatia have expressed a higher level of confidence in the judiciary, police, education, church, health and the EU parliament compared to other parts of Croatia. ${ }^{36}$

32 Franc, R.; Međugorac, V., op. cit., note 30.

33 Mrakovčić, M.; Vuković, D., op. cit., note 6, p. 75-105.

34 At the time of conduction of the survey, Great Britain still was a part of European Union and for that reason, the EU28 label was used.

35 Standard Eurobarometer 90, Nacionalni izvještaj, Javno mnijenje u Europskoj uniji, Europska komisija, 2018, p. 10, https:// ec.europa.eu/croatia/sites/croatia/files/docs/eb90-nat-hr-hr.pdf. Accessed January 22020.

36 Kaliterna-Lipovčan, Lj.; Brajša-Žganec, A., Kvaliteta življenja, sreća, i životno zadovoljstvo u Hrvatskoj i zemljama EU, te usporedbe Sjeverozapadne i ostalih dijelova Hrvatske, Radovi Zavoda za znanstveni rad Varaždin, No. 28, 2017, p. 139-153. https://hrcak. srce.hr/191526. Accessed March 222020. 
It is often the poor institutional environment that represents almost basic brake for (regional) development. The results of an in-depth interview conducted by Drvenkar, highlighted the following obstacles and problems, bureaucracy, centralization of power, corruption, fiscal impositions; while the problem of excessive administrative procedures and bureaucracy is compounded by corruption. ${ }^{37}$ In line with these views is the view expressed by Sekulic and Šporer, which also state that in Croatia the perception of corruption diminishes confidence in all institutions, as well as in the European Union. ${ }^{38}$ According to a source from Transparency International, in 2018, according to the index of perceived level of public sector corruption, the Republic of Croatia is ranked 60 out of 180 countries. Expressed in points, the Republic of Croatia scored 48 and more than two thirds of countries achieve a score below 50, while the average score is at $43 .{ }^{39}$ Evaluations of the level of corruption and business opportunities are also important from a Euro-perspective and it can be linked to a degree of trust in EU institutions. Results of the study by Štulhofer, who was exploring euroscepticism in Croatia, reveal that distrust in the EU partly reflects distrust in national institutions, and, as it states, increase trust in the common good. Furthermore, the implementation of measures that influence the promotion of citizens' confidence in national institutions is an extremely important area of activity, and as shown by some studies cited by the author, citizens' confidence in national institutions is extremely related to the perception of corruption among civil servants. Consequently, increasing trust in national institutions and greater regularity of everyday social transactions should also contribute to reducing distrust in EU institutions. ${ }^{40}$ Taking into account the relative stability of political attitudes as they grow up, as well as the increase in criticality and confidence in political institutions, Gvozdanović concludes that, regardless of the effectiveness of these institutions, in Croatia there will be no quick "recovery" of one type of trust, political trust. ${ }^{41}$

In addition to the opinions presented and the results of research on trust in institutions in the Republic of Croatia by various authors, the authors of this paper conducted in-depth interviews in chosen institutions in two Croatian counties that are going to be presented in the next chapter.

\section{METHODOLOGY AND RESULTS}

The methodology consists of in-depth interviews ${ }^{42}$ made by survey of counsellors or some of leading functions in the chosen academic institutions (institutes/faculties/universities),

37 Drvenkar, N., Reindustrijalizacija kao osnova strategije razvoja Panonske Hrvatske, Sveučilište Josipa Jurja Strossmayera u Osijeku, Ekonomski fakultet u Osijeku, 2012, doktorska disertacija [doctoral thesis].

38 Sekulić, D.; Šporer, Ž., op. cit., note 10.

39 Transparency International. 2018, https://www.transparency.org/country/HRV\#. Accessed December 52019.

40 Štulhofer, A., Euroskepticizam u Hrvatskoj: S onu stranu racionalnosti?, u: Pridruživanje Hrvatske Europskoj uniji: izazovi sudjelovanja, Institut za javne financije, Zagreb, 2006, p. 135-154. http://www.ijf.hr/ Eu4/stulhofer.pdf. Accessed March 22 2020.

41 Gvozdanović, A., Politički utjecaj i vrijednosti kao odrednice političkog povjerenja mladih u Hrvatskoj, Revija za sociologiju, Vol. 44, Issue 1, 2014, p. 5-30. https://hrcak.srce.hr/132054. Accessed March 222020.

42 An in-depth interview is a qualitative research method that involves intensively conducting individual interviews of a small number of respondents, in order to examine their views on a particular research question, program or situation (Boyce i Neale, 
public institutions (administrative departments, county agencies...), business sector institutions (private companies with more than 400 employers) and institutions that promote development (Croatian Chamber of Commerce, Croatian Employers Association) in the City of Zagreb (4) and Osijek-Baranja County (10) during February 2020. Namely, the above model was used in view of the fact that the persons holding leading positions in the academic and business circles, public institutions or publicly owned institutions that promote development, are kind of delegators of implementation and direction of certain changes and movements. In depth interviews in the City of Zagreb are made with four counsellors or some of leading functions in the chosen public administrative departments (Office of the Mayor of the City of Zagreb, Zagreb Innovation Center-ZICER) and institutions that promote development with public authority (Croatian Chamber of Commerce - Zagreb Chamber, Croatian Employers Assciation). In the Osijek-Baranya County in depth interviews are made with ten counsellors or some of leading functions in the chosen academic institutions (dean and two professors dealing with the subject of institutions and researching it), public institutions or administrative departments (Administrative Department for Investments, Development Projects and European Union Funds Institution of Osijek-Baranya County, Regional Development Agency of Osijek-Baranya County, Administrative Department for Social Activities of City of Osijek), institution with public authority that promote development (Croatian Chamber of Commerce, Croatian Employers Asociation) and private sector (director and counsellor of two private companies, both of which are located in or near city of Osijek, with more than 400 employees).

Named two counties are choosen because City of Zagreb is according to Development index of Croatian Ministry of Regional Development, the most developed county of Croatia and therefore classified in the $4^{\text {th }}$ development categorization, while eastern five counties are one of the least developed counties of Croatia, and all of them, besides Osijek - Baranya County that belongs to the $2^{\text {nd }}$ development categorization, belong to the $1^{\text {st }}$ development categorization according to the same Development index. Having in mind that Osijek-Baranya County is most developed among counties of Eastern Croatia, author's wanted to test if institutional trust is different among different development counties categorization, according to named index. Besides, city of Osijek presents regional center for Eastern part of Croatia, and achieved institutional trust plays significant role and should be taken into account. Research of Drvenkar $^{43}$ served as a methodology example when conducting in-depth interview. Namely, persons holding leading positions in the academic and business circles, as well as in public or the state sector, are kind of delegators of implementation and direction of certain changes and movements. In all the aforementioned institutions, the selected respondents are, for example, when it comes to the academic community, board members or scholars who, in their work, have dealt with the importance of institutions and their development. When it comes to examining trust in institutions in the business sector, an in-depth interview was conducted in business entities classified as large companies, namely persons who are directors of the company, or hold important business positions in the overall development of the company. In public sector institutions, in-depth interviews were conducted with the heads of the institution or the deputy heads. As all respondents are able to define specific behavioral frameworks within

2006:3). See more: Boyce, C.; Neale, P., Conducting In-depth Interviews: A Guide for Designing and Conducting In-Depth Intervies for Evaluation Input, Pathfinder International Tool Series Monitoring and evaluation - 2, 2006. http://www2.pathfinder.org/site/ DocServer/m-e-tool-series-indepth-interviews.pdf. Accessed June 92020. 
the community/institution in which they operate in a certain way, and given the importance of all selected positions, it is clear that their influence on the local community is extremely large and important.

The in-depth interview respondents were also asked questions about the confidence rating in the selected institutions. They were asked to assign, in their opinion, an adequate and associated Likert scale score, from 1 to 5 , with the results of the assessment representing the following: 1 = I do not trust at all; 2 = mostly distrustful; 3 = neither trust nor distrust; 4 = I mostly trust; 5 = I trust completely. The list of institutions for which trust in the institutions has been tested has been compiled according to the census from the Mrakovčić and Vuković (2019) survey and expanded with additional institutions.

\subsection{RESULTS OF CONDUCTED RESEARCH: CITY OF ZAGREB}

In the City of Zagreb, all advisers believe that trust in institutions ensures functioning of the sector and thus encourages entrepreneurship, creation of new values, a framework for behaviour and action. With regard to individual constituents in institutions, counsellors believe that family is crucial and that trust and connection are built from the earliest days into the family, we know each other best (strengths, weaknesses, knowledge and skills of each individual member) and it is easier to build on such a foundation, and to develop family entrepreneurship. The education system is characterized by the slow adoption of new technologies and the unpreparedness of examples; it is a flexible and sluggish system, where there is great resistance to necessary changes, insufficient and unclear communication between the founders, institutions and relevant stakeholders. Expenditure on education and science is largely related to the level and distribution of income collected by the relatively high tax burden paid by the private business sector in Croatia.

According to the latest European Commission EU Report (Education and training monitor 2019), Croatia allocates $4.7 \%$ of GDP to education, while the EU average is $4.6 \%$ of GDP, and according to Eurostat data, the share of education expenditure in the Croatian budget is $10.5 \%$ of GDP, while the EU average is slightly lower at $10.2 \%$ of GDP. ${ }^{44}$ In such conditions, entrepreneurs and citizens expect a much better quality and system appropriate to today's era of accelerated technology development and the changes they bring in society and the economy. Counsellors believe that there is room for improvement and that greater responsibility should be given to teachers. Scientific institutions are characterized by slow adoption of new technologies and sluggish attitude towards change, but despite some excellent examples (individuals and organizations). Overall, scientific institutions are primarily self-directed and often feel as their purpose is themselves. This means that they are insufficiently linked to the economy and real life. In addition, they have minimal impact on the economy and are not a corrective factor for society.

44 European Commission, Education and training Monitor 2019, Publications Office of the European Union, Luxembourg, 2019, DOI: 10.2766/442033. Accessed April 32020. 
The Government of the Republic of Croatia is marked by the lack of a vision, a mechanism for long-term planning and management, a lack of strategic guidelines and a national development plan for Croatia, and no clear strategic economic and demographic goals. Advisers consider political parties marked by unclear goals, priorities and inconsistencies. In addition, they believe that they absolutely lack the sense and purpose of existence and action, that quality of staff within political parties is very poor and that experts are marginalized. Advisers believe that the biggest obstacle to trust in institutions is corruption, inconsistency in decision-making and enforcement, non-compliance as well as slow and complicated procedures. Also, the value system of the social framework, apathy, a burden of the past, process transparency, exclusivity, corruption and arrogance of politicians, civil servants and public officials are very frequent. The obstacles that businessmen encountered while working, which were directly the result of low confidence in institutions are as listed: slow or inadequate response to referred initiatives, poor staffing in institutions, system information inoperability, non-updated systems, uninformed and inadequately educated state and public administration employees, inefficient, costly and over-administration (lost forms and documents, failure to meet deadlines, ignorance of own system, regulations, unwillingness to change, etc.).

The opinion of advisers that an effective and independent judiciary, a larger publicity of work, effective control mechanisms will lead to improved confidence in the institutions, regardless of the levels of government. They contribute to public evaluation of the work of public and civil servants. Transparent spending of public funds, real-time monitoring of the work of public and civil servants, transparency, efficiency, focus on achieving goals and the reasons for setting up institutions are the real reasons that contribute to this. The absurd legal procedure, the repression of inspections, the repression of the finance administration, mostly dominates, but not the knowledge and repression of most institutions. It is the opinion of the advisers that they are responsible for the current values of trust in the institutions of the political system at all levels of political power. In particular, the judiciary, while the citizens of Croatia themselves do not participate sufficiently in democratic processes, remain with established values and attitudes, beliefs about bad experiences from the past. From the same, there is no vision for the development of society, creation of a good and responsible, long-term placement and management of the system.

\subsection{RESULTS OF CONDUCTED RESEARCH: OSIJEK - BARANYA COUNTY}

The results in other county of Croatia where questionary was conducted, Osijek-Baranya County, did not show a lot of different attitudes of respondents when compared to City of Zagreb. A unique attitude of respondents was expressed concearning the stance that trust in institutions is an important part for the advancement of the economy, for instance in following attitudes: "Yes. They must be closely linked to the economy" or "They regulate and reduce uncertainty in the economy."; as well as unique attitudes in increase of trust in institutions in order to facilitate business activities: "It facilitates business processes because it speeds up administrative procedures, enables clear and transparent procedures and processes" or "Yes. Because it should allow the development process to be completed without additional barriers." 
When grading their level of trust in institutions we can confirme that most of their attitudes are in accordance to already conducted analysis, although with some major differences in certain institutions, what can be a part of their own views. When it comes to family trust, most respondents, regardless of questionnaried community, have their attitude as generally trusted (4) or fully (5) trusted it. Some of explanations are that family brings together different generations, has a common interest, gives a cultural norms and values that are crucial for the development of the family and further standards and can give criteria in evaluation of other peole, processes and institutions. Unlike a high level of trust in the family, trust in the educational system is different within communities. Respondents rate the system from being generally not trusted to fully trusted. There are several standpoints: "Experiences in the educational process greatly create a perception of where you will live and work. One part comes from home and a large one from the education system"; while, on the other hand, positions such as "I mostly don't trust it" are recorded.

When it comes to trust in scientific institutions, respondents either generally trusted them or neither trust or distrust the institutions. In expressing confidence in the Government, the respondents mostly expressed that they generally do not trust it or are at the level of neither trusting nor distrusting, with some exceptions in form of complete confidence, but also ratings expressing no trust in the institutions at all, for instance "As far as projects and political decisions are concerned, I have confidence in that, but unfortunately because of individuals and their scandals, the trust is broken." The political parties were generally rated that they generally did not trust this institution and confirmed this with the following statements; "Two, not to say one" or "They are viewed as a group, so it is difficult to express a specific level of trust. They usually have a hard to believe program. Although they cite the program during the campaign period as an essential element of the election campaign, they do not present it to the public in terms of the realized program results. At the state level, there is a lack of presentation of the results." Grading the local government, the respondents gave different grades from the lowest of no confidence to the generally trust it level. Aforementioned indicates that the attitudes are largely created by their own experience in relation to local institutions.

The evaluation of the military was generally that the respondents generally trusted it, or even fully trusted it:"Traditional trust, because of faith in the pillars of society, protection and defense, as well as war experience, where trust in these institutions was necessary." However, there is only one attitude that is completely lacking in confidence: "Our military is non-existent, no weapons, it is not sufficiently trained." indicating, according to the previous research on the level of Croatia, that usually younger generations do not have strongly exressed traditional views of trust.

The police as an institution that the respondents generally neither trust or distrust, or they generally trust it because of an attitude of traditional trust in the pillars of society, with the rationale for trust in the police being the same as in the military. Confidence in the Church expressed by the respondents is at the level that they generally trust it, but there are both highest and lowest levels of trust in two cases. Trust in the media is completely different among respondents, and in terms of quantity three groups of trust could be formed, from the level of generally do not trust, across neither trust or distrust it, and ending with generally trusting it. Some of the statements: "Inherited from the previous system, legal and political. It is slowly losing its function and meaning."; "I think that the union is a politicized institution in a certain way."; "Be- 
cause in our country, unions do not have their true function. I believe that they are overpaid without adequately representing us." Trust in non-governmental organizations is generally rated neither trust nor distrust attitude: "[...] We do not have a real civilian sector and NGOs like in western countries. They are instrumentalised by the politics." However, there are also views with generally do not trust and complete confidence in it: "Because citizens' associations enthusiastically want to correct what they have found to be faulty, and the state apparatus could not resolve a certain situation. We need to encourage them to get involved, but it also shows the strength and democracy level of society. It also shows the level of development."

The prevailing trust rating in the EU is expressed with mostly trust it, "I still believe in EU law."; "Clearly defined responsibilities, rules and procedures. Like a well-structured system. Functional diversity." Respondents' views on confidence in the Croatian Parliament are generally expressed in grade "The same as with political parties." Still, there are some lower grades from respondents belonging to business/private sector, with the view, "Same as political parties and government", but also a slightly higher grade in one respondent belonging to an institution of academic community. An important issue was to see what do representatives and head of institutions see as the biggest obstacle in achieving the trust in institutions, were for instance, "Nepotism, scandals, over-influence of politics"; "Mediocratism, questionable (non) expertise"; "Corruption, ignorance, unprofessionalism"; "Incompetence"; "The inefficiency of what they are actually designed for"; "The society is politicized in the public space, negative news [...] bring a bad image to institutions although culprits are individuals, and we tend to generalized." In trying to find the potential solutions for low levels of trust in institutions, authors wanted to see what is needed, in respondents opinion, to be improved in order to improve confidence in institutions and the common denominator was transparency (refering to different context), objectification, strengthening trust in the administration and the justice system, improvement in sanctioning omissions. For instance: "Objectification of the media (objective, investigative journalism - affirmations of investigative journalism, more transparent procedures, fewer administrative issues" or "In some way remove politics from all these institutions and introduce expertise as musch as possible". When listing obstacles encountered during work that were directly the results of low confidence in institutions, respondents listed following: slow response, acting in accordance with the law, longevity of procedures, incompetence, unflexible, breakness of deadlines, etc. When asked about who's responsibility they think is of the current values of trust in institutions, respondents have mostly singled out Government and Parliament and after this one, media and judiciary. Some of their statements are for instance following: "There is always the Government and Parliament", "Media; political irresponsibility" or "The judiciary is first and foremost".

\section{CONCLUSION}

Research on trust in institutions needs an interdisciplinary approach and is not related only to the economic effects and science. Importance of institutional trust consists of idea that its building is central in building democratic societies. Besides, it also can serve as a great indicator of satisfaction with current regime and situation or be the reason for the current situation and subsequently impact economic growth and standard of life. Theoretical findings from some of the studies cited in the paper show that the general population of the Republic 
of Croatia has extremely low confidence in certain institutions. The assumption of the study of institutional trust in this paper is based on a survey of the perceptions and attitudes of selected respondents of the academic community, business community, state sector, as well as institutions with public authorities in two counties of the Republic of Croatia, the City of Zagreb and Osijek-Baranya County. Although mentioned counties, have different development levels (according to the Development index measured by the Ministry of Regional Development and European funds), $4^{\text {th }}$ and $2^{\text {nd }}$ group categorization, respectively, respondents on certain questions had very similar perceptions and attitudes - on the other hand, certain perceptions and attitudes differed between, but also within the same county. Certain theoretical parts of the paper on levels of trust are very similar to and almost completely confirmed in the empirical part of the paper, althought the level of development differences would probably be more emphasized in the results when conducting the research within general population than within this obtained research - since the research included leading institutional positions that demand also similar qualifications of people holding those positions.

Independent of the county in which the survey was conducted, as well as the institution the respondents belong to, they stated that trust in the institutions is extremely important for the development of the economy, reducing and regulating uncertainty in the economy as well as being crucial in the process of creating new values. Transparency of the work of institutions was cited as very important. When stating and asking whether trust in institutions increases the conduct of a business process, respondents is unanimous in stating that it facilitates it. Respondents views on the biggest obstacles to trust in institutions relate to some of the following: corruption, inconsistency in decision-making and enforcement, non-compliance, slow and complicated procedures, the value system of the social framework, apathy, history, non-transparency, exclusivity, arrogance of politicians, civil and public servants, ineffective and insufficient problem solving, nepotism, employment of persons who are inadequate for the positions they hold, decision-making control system, politization, inclination, ignorance, unprofessionalism, mediocratism, questionable expertise, scandals, incompetence. This makes it clear what has the most disturbing effect on confidence in institutions and, consequently, to the development of the economy. In line with the obstacles to trust in institutions, answers to the questions about what is needed to be improved in order to improve the trust in institutions, it is pointed into creating efficiency and (judiciary) independence, transparent spending of public funds and monitoring the work of public servants, as well as their employment, appreciation of the profession, investigative journalism, reduction of administrative matters and barriers, hiring of experts, open communication, community involvement. The answers given are at the same time suggestions of potential improvements in the cited counties. Although these two counties were covered by the survey, it is clear that fulfilling and improving these recommendations would significantly improve the overall development of all counties in the Republic of Croatia. The author's assumption is that these obstacles, as well as suggestions, would be repeated when conducing the research in other counties of the Republic of Croatia and it is also one of future research aims and limitation of conducted research. Thus, as a rule, the obstacles are almost identical, with slight differences compared to these counties and some positive or negative deviations in certain counties. The important issue of the responsibility for low level of confidence in the selected two counties in the results points to the views of the respondents on the responsibilities of the holders of political power, the state system 
and institutions, the government and parliament, the judicial system, but also the citizens themselves, given their insufficient participation in democratic processes.

In line with the stated views, it is clear to conclude a low level of trust in chosen institutions of the respondents. Slightly higher level of trust is noted in the family as an institution while confidence in political parties is at a very low level. Confidence in trade unions as an institution is also quite low. Extreme gap in trust is present for the military, the Church and the educational system, which obviously depends largely on their own perception of the institutions, i.e. traditional values in relation to contemporary views and acceptances of particular institutions and the values attached to them. Furthermore, a considerable gap has also been observed in grades for local self-government, which implies that one's own experiences in the form of particular (non)cooperation results in a specific assessment of trust in local self-government institutions. When it comes to trusting non-governmental organizations, it is important to note that some of the respondents referred to the importance of the non-governmental sector as an indicator of a democratic society, but also mentioned the need to create a non-governmental sector much more similar to the one in Western countries.

All of institutions presented in the survey could be a drivers of changes at local and regional level. According to given opinionis of respondents, it is therefore, extremely important, to include some of respondents suggestions in the future documents and decision-making. For instance, linking the economy with real life, so that they could become a corrective factor for society and economy. In the future research, it would be good to include a survey on all counties of Croatia and chosen institution representatives. Besides, it would be of a great benefit to make a survey of institutional trust perception of the general population. Afterwords, these results could be compared and in a certain way changes in attitude could be tracked. Theoretical knowledge and framework of institutional trust match greatly with the results of this research. Although the research results due to subjectivity of interview as a method could be taken with caution in interpretation as well as with sample size, it is inevitable to understand the above obstacles presented in the paper and create and adapt legislative framework and economic policy instruments in order to increase possible positive effects of institutional trust on the local, regional and national level.

\section{REFERENCES}

1. Aralica, Z.; Budak, J., Institutional Development and Good Governance Assessments in Croatia: An Extended Focus on Corruption, Zagreb International Review of Economics \& Business Conference Issue, SCI (1), 2004, p. 17-34. https://hrcak.srce.hr/101270. Accessed March 222020.

2. Baloban, S.; Rimac, I., Povjerenje u institucije, Bogoslovska smotra, Vol. 68, Issue 4, 1998, p. 663-672. https://hrcak.srce.hr/31611. Accessed March 222020.

3. Bejaković, P., Labor Force Competitiveness in Croatia: Status and Problems, in: Konkurentnost hrvatske radne snage [Competitiveness of the Croatian Labor Force], Institut za javne financije, Zagreb, 2004, p. 1-13.

4. Boyce, C.; Neale, P., Conducting In-depth Interviews: A Guide for Designing and Conducting In-Depth Intervies for Evaluation Input, Pathfinder International Tool Series Monitoring and evaluation-2, 
2006. http://www2.pathfinder.org/site/Doc Server/m-e-toolseries-indepth-interviews. pdf. Accessed June 62020.

5. Campbell, W. R., The Sources of Institutional Trust in East and West Germany: Civic Culture or Economic Performance?, German politics, Vol. 13, Issue 3, 2007, p. 401-418. DOI: 10.1080/0964400042000287437. Accessed March 222020.

6. Cole, L.; Cohn, E., Institutional Trust Across Cultures: Its Definitions, Conceptualizations, and Antecedents Across Eastern and Western Euroean Nations, u: Interdisciplinary Perspectives on Trust: Towards Theoretical and Methodological Integration, Springer, Cham-Heidelberg-New York-Dordrecht-London, 2016, p. 157-176. DOI: 10.1007/978-3-319-22261-5. Accessed April 32020.

7. Drvenkar, N., Reindustrijalizacija kao osnova strategije razvoja Panonske Hrvatske, Sveučilište Josipa Jurja Strossmayera u Osijeku, Ekonomski fakultet u Osijeku, 2012, doktorska disertacija [doctoral thesis].

8. European Commission, EU Report, Education and training Monitor 2019, Publications Office of the European Union, Luxembourg, 2019. DOI: 10.2766/442033. Accessed April 32020.

9. Franc, R.; Međugorac, V., Mladi i (ne)povjerenje u institucije: moguće odrednice i posljedice, u: Demokratski potencijali mladih u Hrvatskoj, Institut za društvena istraživanja u Zagrebu, Centar za demokraciju i pravo Miko Tripalo Zagreb, Zagreb, 2015, p. 47-65.

10. Gvozdanović, A., Politički utjecaj i vrijednosti kao odrednice političkog povjerenja mladih u Hrvatskoj, Revija za sociologiju, Vol. 44, Issue 1, 2014, p. 5-30. https://hrcak.srce.hr/132054. Accessed March 222020.

11. Habibov, N., Individual and Country-level Institutional Trust and Public Attitude to Welfare Expenditures in 24 Transitional Countries, The Journal of Sociology \& Social Welfare, Vol. 41, Issue 4, 2014, p. 23-48. https://scholarworks. wmich.edu/jssw/vol41/iss4/3. Accessed March 222020.

12. Habibov, N.; Cheung, A.; Auchynnikava, A., Does Institutional Trust Increase Willingness to Pay More Taxes to Support the Welfare State?, Sociological Spectrum, Vol. 38, Issue 1, 2018, p. 51-68. DOI: 10.1080/02732173.2017.1409146. Accessed March 222020.

13. Hakhverdian, A.; Mayne, Q., Institutional Trust, Education, and Corruption: A Micro-Macro Interactive Approach, The Journal of Politics, Vol. 74, Issue 3, 2012, p. 739-750. DOI: abs/10.1017/ S0022381612000412. Accessed March 222020.

14. Hudson, J., Institutional Trust and Subjective Well-Being accroaa the EU, Kyklos, International Review for Social Sciences, Vol. 59, Issue 1, 2006, p. 43-62. DOI: 10.1111/j.1467-6435.2006.00319. Accessed March 222020.

15. Hwang, I. D., Which Type of Trust Matters?: Interpersonal vs. Institutional vs. Political Trust, Seoul: Bank of Korea WP 2017-15, 2017. http://dx.doi.org/10.2139/ssrn.2967051. Accessed January 11 2020.

16. Kaliterna-Lipovčan, Lj., Brajša-Žganec., A. Kvaliteta življenja, sreća, i životno zadovoljstvo u Hrvatskoj i zemljama EU, te usporedbe Sjeverozapadne i ostalih dijelova Hrvatske, Radovi Zavoda za znanstveni rad Varaždin, No. 28, 2017, p. 139-153. https://hrcak.srce.hr/191526. Accessed March 222020.

17. Matić, D., Demokracija, povjerenje i socijalna pravda, Revija za sociologiju Vol. 31, Issue 3-4, 2000, p. 183.-195. https://hrcak.srce.hr/154303. Accessed March 222020.

18. Mrakovčić, M., (Dez)integracija i povjerenje u institucije u višeetničkim zajednicama Hrvatske, Revija za sociologiju Vol. 40, Issue 2, 2010, p. 157-184. https://www.ceeol.com/search/article-detail?id=45778. Accessed March 222020.

19. Mrakovčić, M.; Vuković, D., 'Unutarnja' kriza pravosuđa? Stavovi pripadnika pravničkih profesija o pravoduđu u Hrvatskoj i Srbiji, Politička misao, Vol. 56, Issue 1, 2019, p. 75-105. DOI: 10.20901/ pm.56.1.03. Accessed March 222020. 
20. Moreno, E. A., Ghezzi, A., Gemo, M., Tallacchini, M., Pereira, A. G., Institutional Trust: Beyond Transparency, Luxembourg: Euopean Commission, JRC Science and Policy Reports, 2014. https://publications.jrc.ec.europa.eu/repository/bitstream/ JRC93048/lbna2728 6enn.pdf. Accessed April 2 2020 .

21. Nooteboom, B., Social Capital, Institutions and Trust, Review of Social Economy, Vol. 65, Issue 1, Beyond Social Capital, 2007, p. 29-53. DOI: 10.1080/00346760601132154. Accessed March 222020.

22. OECD, OECD Guidelines on Measuring Trust, OECD Publishing, Paris, 2017. http://dx.doi. org/10.1787/9789264278219-en. Accessed December 52020.

23. Sekulić, D.; Šporer, Ž., Gubimo li povjerenje u institucije?, u: Korupcija i povjerenje, Centar za demokaciju i pravo, Zagreb, 2010, p. 71-117. https://tripalo.hr/knjige/KorIPovj/sekulicSporer.pdf. Accessed March 222020.

24. Smith, M., Building institutional trust through e-government trustworthiness cues, Information Technology \& People, Vol. 23, Issue 3, 2010, p. 222-246. DOI: 10.1108/09593841011069149. Accessed March 222020.

25. Standard Eurobarometer 90, Nacionalni izvještaj, Javno mnijenje u Europskoj uniji, Europska komisija, 2018. https://ec.europa.eu/croatia/sites/croatia/files/docs/eb 90-nat-hr-hr.pdf. Accessed January 22020.

26. Štulhofer, A., Euroskepticizam u Hrvatskoj: S onu stranu racionalnosti?, u: Pridruživanje Hrvatske Europskoj uniji: izazovi sudjelovanja, Institut za javne financije, Zagreb, 2006, p. 135-154. http:// www.ijf.hr/Eu4/stulhofer.pdf. Accessed March 222020.

27. Transparency International. 2018. https://www.transparency.org/country/HRV \#. Accessed December 52019.

28. Trzun, Z., Kriza povjerenja u institucije: Istraživanje povjerenja u vojsku, Polemos: časopis za interdisciplinarna istraživanja rata i mira, Vol. 15, Issue 29, 2012, p. 33-54. https://hrcak.srce.hr/92832. Accessed March 222020.

29. Ward, P. R.; Miller, E.; Pearce, A. R.; Meyer, S. B., Predictors and Extent of Institutional Trust in Government, Banks, the Media and Religous Organisations: Evidence from Cross-Sectional Surveys in Six Asia-Pacific Countries, PLoS One, Vol. 11, Issue 10, 2016, DOI: 10.1371/journal.pone.0164096. Accessed March 222020.

30. Welter, F.; Smallbone, D., Exploring the Role of Trust in Entrepreneurial Activity, Entrepreneurship, Theory \& Practice, Vol. 30, Issue 4, 2006, p. 465-475. DOI: 10.1111/j.1540-6520.2006.00130.x. Accessed March 222020.

31. Zsolt, B.; Gergo, M.-B., Does Institutional Trust in East Central Europe Differ from Western Europe?, European Quarterly of Political Attitudes and Mentalities, Vol. 3, Issue 2, 2014, p. 1-17. https:// search.proquest.com/openview/da2c0270 3e0fcb22da31383885a32b08/1?cbl=203088. Accessed March 222020. 
Dubravka Jurlina Alibegović*

Katarina Marošević ${ }^{* *}$

\section{INSTITUCIONALNO POVJERENJE U SLUČAJU HRVATSKIH REGIJA}

\section{Sažetak}

U suvremenoj literaturi institucije i institucionalno povjerenje označavaju važne odrednice (regionalnog) rasta i razvoja. Cilj je ovog rada analizirati institucionalno povjerenje u dvije hrvatske županije i usporediti te rezultate s ranijim teorijskim nalazima. Metodologija se sastoji od dubinskih intervjua obavljenih anketom među savjetnicima ili nositeljima vodećih funkcija u dvije hrvatske županije.

Rezultati su uglavnom u skladu s ranijim nalazima prema teoriji institucionalnog povjerenja na hrvatskoj razini, tj. najviša razina institucionalnog povjerenja povezuje se s tradicionalnim vrijednostima, npr. s obitelji, dok je u nekim institucijama povjerenje variralo i postojao je jaz na razini povjerenja ispitanika, ovisno o vlastitu iskustvu, npr. u sustavu samouprave i obrazovanja. Na vrlo niskoj razini institucionalnog povjerenja, na primjer, nalaze se političke stranke i vlada. Navodi se da su neke od glavnih zapreka u postizanju visoke razine institucionalnog povjerenja korupcija, nedosljednost u donošenju i provedbi odluka, nepoštovanje zakona, spori i komplicirani postupci, netransparentnost, politizacija. Povjerenje u institucije, prema rezultatima istraživanja, utječe na smanjenje i regulaciju nesigurnosti u gospodarstvu. Ti bi rezultati mogli biti vrlo vrijedni i određeni vodič za tvorce politika i za njihovo donošenje odluka u budućnosti.

Ključne riječi: $\quad$ institucije, regionalni razvoj, Republika Hrvatska

\section{(c) (1) (\$)}

This work is licensed under a Creative Commons

Attribution-NonCommercial 4.0 International License.

\footnotetext{
* Dr. sc. Dubravka Jurlina Alibegović, Ekonomski institut, Zagreb, Trg J. F. Kennedyja 7, 10000 Zagreb. E-adresa: djurlina@eizg.hr. ORCID: https://orcid.org/0000-0002-0424-7583.

** Dr. sc. Katarina Marošević, docentica Pravnog fakulteta Sveučilišta Josipa Jurja Strossmayera u Osijeku, S. Radića 13, 31000 Osijek. E-adresa: katarina.marosevic@pravos.hr. ORCID: https://orcid.org/0000-0002-8727-130X.
} 